\title{
$\alpha$-Substituted 1-Aryl-3-dimethylaminopropanone Hydrochlorides: Potent Cytotoxins towards Human WiDr Colon Cancer Cells
}

\author{
Hari Narayan PATI,${ }^{a}$ Umashankar Das,${ }^{a}$ Irving Javier RAmirez-Erosa, ${ }^{b}$ Donna Mae Dunlop,${ }^{b}$ \\ Robert Allan HICKIE, ${ }^{b}$ and Jonathan Richard Diммоск ${ }^{*, a}$ \\ ${ }^{a}$ College of Pharmacy and Nutrition, University of Saskatchewan; 110 Science Place, Saskatoon, Saskatchewan S7N 5C9, \\ Canada: and ${ }^{b}$ Department of Pharmacology, College of Medicine; 107 Wiggins Road, Saskatoon, Saskatchewan S7N 5E5, \\ Canada. Received May 24, 2006; accepted January 29, 2007
}

A series of 1-aryl-2-dimethylaminomethyl-2-propenone hydrochlorides 1 were prepared which possessed $\mathrm{IC}_{50}$ values of less than $10 \mu \mathrm{M}$ when examined towards human WiDr colon cancer cells. The related 1-aryl-2-dimethylaminomethyl-3-hydroxypropanone hydrochlorides 2, formed by hydration of the analogs in series 1 , also had $\mathrm{IC}_{50}$ values in the low micromolar range. On the other hand, conversion of 2-dimethylaminomethyl-1-(4-nitrophenyl)-2-propenone hydrochloride $1 \mathrm{c}$ into the corresponding 2 -mercaptoethanol of adduct $3 \mathrm{c}$ led to a 37 -fold reduction in potency. Two thirds of the compounds prepared in this study were more potent than a reference drug cisplatin while one third of these molecules displayed greater cytotoxicity to the WiDr cells than human CRL-2522 fibroblasts. A stability study of the 4-nitrophenyl analog in each of the series $1-3$ in deuterium oxide was undertaken. In the case of $1 \mathrm{c}$, replacement of the dimethylamino hydrochloride group by a hydroxy function was noted while in series 2 , the loss of both water and dimethylamine hydrochloride gave rise to a mixture of two enones. The mercaptoethanol adduct $3 \mathrm{c}$ underwent deamination. The data obtained provide guidelines for amplifying the project in the future.

Key words cytotoxicity; 1-aryl-3-dimethylaminopropanone; stability study; colon cancer

A number of different series of $\alpha, \beta$-unsaturated ketones have been synthesized in our laboratories as candidate antineoplastics. ${ }^{1,2)}$ These compounds were designed as thiol alkylators. Conversion of various conjugated arylidene ketones into the corresponding Mannich bases led to compounds with substantially increased rates of reaction with a model thiol which was attributed to greater stabilization of the reaction intermediate as well as solvation effects. ${ }^{3)}$ Several studies revealed that Mannich bases of enones reacted with thiols but not with amino and hydroxy groups. ${ }^{4,5}$ Hence the genotoxic properties of a number of anticancer drugs currently in use ${ }^{6)}$ may be absent with these compounds. In addition, since Mannich bases of conjugated arylidene ketones are structurally divergent from current anticancer drugs, the problem of their being cross-resistant to established medication may be absent. The disclosure that several drug-resistant cell lines were free from cross-resistance to a number of Mannich bases of conjugated arylidene ketones ${ }^{7)}$ supports this contention.

Earlier investigations from these laboratories described the noteworthy antineoplastic properties of the 1-aryl-2-dimethylaminomethyl-2-propenone hydrochlories. ${ }^{8)}$ Thus the $\mathrm{IC}_{50}$ values of 1a, e towards a panel of human tumor cell lines are 6.92 and $4.07 \mu \mathrm{M}$, respectively. In addition, the weights of various human tumor xenografts passaged in athymic mice were reduced by several of these compounds, e.g., 1a, e caused a reduction in the growth of the COLO 205 colon cancer by 40 and $45 \%$, respectively, while the weight of the PC-3 prostate tumor was lowered by $61 \%$ by 1e. A dose of $4 \mathrm{mg} / \mathrm{kg}$ of 1a increased the life span of mice with Ehrlich ascites carcinoma by $282 \%$ which was increased to $322 \%$ when the compound was formulated in niosomes. All mice inoculated with $\mathrm{B}_{16} \mathrm{~F}_{1}$ melanoma were dead after $60 \mathrm{~d}$. However the percentage survivors of animals receiving $4 \mathrm{mg} / \mathrm{kg}$ of $1 \mathrm{a} 60$ and $230 \mathrm{~d}$ after administration of the Mannich base were 30 and 10; these figures were increased to 40 and 20 when the compound was formulated in niosomes. The conclusions from this study were that the 1-aryl-2-dimethylaminomethyl-2-propenone hydrochlorides are promising lead compounds and their gradual release in vivo improved the bioactivity.

A review of the literature revealed that a number of investigations have been undertaken with a view to determining the modes of action of 1-aryl-2-dimethylaminomethyl-2propenone hydrochlorides and adducts derived from these compounds. A previous study from our laboratory revealed that 1a is a potent inhibitor of respiration in mitochondria isolated from mouse liver cells having an $\mathrm{ID}_{50}$ value (the concentration required to inhibit respiration by $50 \%$ ) of $\left.1.14 \mu \mathrm{M} .{ }^{9}\right)$ The antimitochondrial properties of $\mathbf{1} \mathbf{a}$ and related compounds were attributed to the presence of an enone group and a basic centre located two carbon atoms from the carbonyl function, while hydrophobicity also influenced potencies. Other investigators observed that $\mathbf{1 a}, \mathbf{b}, \mathbf{e}$ and related compounds inhibited tubulin polymerization. ${ }^{10,11)}$ The shape of platelets is maintained by its microtubular cytoskeleton ${ }^{12)}$ and the secretion of lipoproteins into the extracellular space is influenced by the microtubular system. ${ }^{13)}$ Compounds $\mathbf{1 a}, \mathbf{b}, \mathbf{e}$ and related analogs inhibited human ADP-induced platelet aggregation. ${ }^{10)}$ A preliminary report revealed that 1a and two analogs decreased the serum concentrations of triglycerides and cholesterol in rats treated with Triton WR 1339 which induces hyperlipidemia in these animals. ${ }^{14)} \mathrm{A}$ subsequent study with $\mathbf{1 a}, \mathbf{b}, \mathbf{e}$ and analogs also reported this phenomena as well as revealing an increase in phospholipids. These studies confirm that an important site of action of these compounds is the microtubules. In addition, 1a selectively inhibited a protein tyrosine kinase (PTK), namely epidermal growth factor receptor (EGFR) in contrast to having minimal or no effects on other tyrosine or serine/threonine kinases. ${ }^{15)}$ An analog of $\mathbf{1 a}$ in which a 4-benzyloxy group was placed in the aryl ring was reacted with various thiols to 


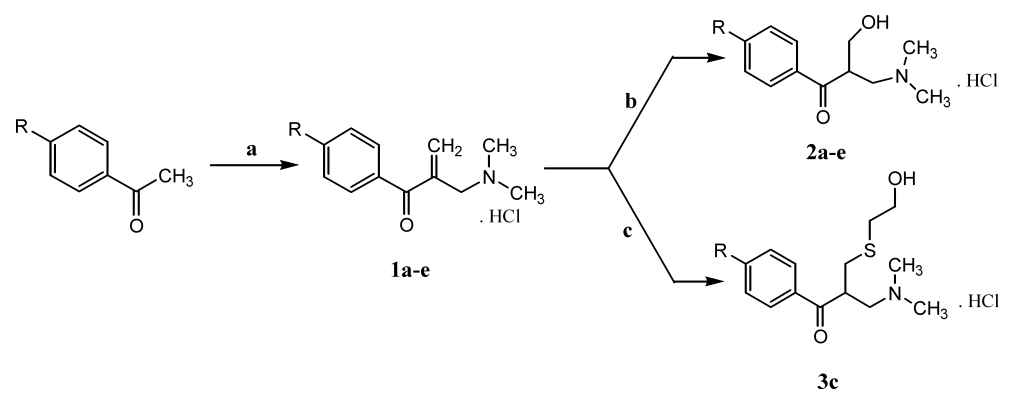

a: $\mathrm{R}=\mathrm{H} ; \mathbf{b}: \mathrm{R}=\mathrm{Cl} ; \mathbf{c}: \mathrm{R}=\mathrm{NO}_{2} ; \mathbf{d}: \mathrm{R}=\mathrm{CH}_{3} ; \mathbf{e}: \mathrm{R}=\mathrm{OCH}_{3}$

Chart 1. Synthetic Chemical Pathway for Preparing Compounds in Series 1-3

The reagents used were as follows: a. $2 \mathrm{HCHO}, \mathrm{NH}\left(\mathrm{CH}_{3}\right)_{2} \cdot \mathrm{HCl}$, b. $\mathrm{H}_{2} \mathrm{O} / \mathrm{pH}=8-9$, c. $\mathrm{HSCH}_{2} \mathrm{CH}_{2} \mathrm{OH}$.

give the corresponding adducts which also showed a selective inhibition of the activity of EGFR PTK. Evaluation of 1a and several thiols adducts against murine BALB/MK epidermal keratinocytes, whose proliferation depends on $\mathrm{EGF},{ }^{16)}$ revealed that a number of compounds had $\mathrm{IC}_{50}$ values in the low micromolar range. ${ }^{15)}$ Furthermore, flow cytometric analysis of 1a revealed that cell cycle transit in murine P388 leukemia cells was completely blocked and there was no evidence of any phase-dependent effects. ${ }^{17)}$ Thus in addition to specific sites of action, namely mitochondria, microtubules and at least one PKT, 1a (and presumably its analogs in series 1 and 2) has additional sites of action such as different phases of the cell cycle. Since cancer cells are dysregulated causing a myriad of aberrant biochemical reactions, the value of multifunctional compounds is clear. In fact, the value of the marked pleiotropy of candidate cytotoxins has recently been articulated. ${ }^{18)}$

The objectives of the present study were to prepare a number of prototypic molecules in order to formulate guidelines as to how the project should be amplified. The specific series of compounds $\mathbf{1}-\mathbf{3}$ are presented in Chart 1 and the design of these molecules was based on the following considerations. In regard to the aryl substituents, groups with widely differing physicochemical properties were chosen. The Hammett sigma $(\sigma)$ and Hansch pi $(\pi)$ values of these substituents are a measure of their electronic and hydrophobic properties, respectively. Hence groups with positive $(+)$ and negative ( -$) \sigma$ and $\pi$ values were chosen, namely chloro $(+,+)$, nitro $(+,-)$, methyl $(-,+)$ and methoxy $(-,-)$ which are found in $\mathbf{b}-\mathbf{e}$, respectively. In addition, the molar refractivity (MR) figures for the hydro, chloro, nitro, methyl and methoxy groups are 1.03, 6.03, 7.36, 5.65 and 7.87, respectively. ${ }^{19)}$ Since a gradual release of 1 a improved bioactivity vide supra, the aminoalcohols $\mathbf{2 a}$ - e were suggested which may undergo dehydration to liberate the corresponding enones 1a-e. The conjugated unsaturated aldehyde acrolein, which is a metabolite of cyclophosphamide, gives rise to cystitis which may be ameliorated by the coadministration of a thiol. ${ }^{20)}$ In order to examine the possibility that cytotoxicity would be retained and a thiol liberated, the formation of the thiol adduct 3c obtained from 1c was suggested.

Chemistry Reaction of various 1-arylethanones with dimethylamine hydrochloride and excess of paraformaldehyde led to the formation of the Mannich bases $1 \mathbf{a}-\mathbf{e}$. These compounds reacted readily with water producing the correspon- ding aminoalcohols 2a-e. 2-Mercaptoethanol condensed with $\mathbf{1 c}$ to give the thiol adduct $\mathbf{3 c}$.

Representative compounds in each series, namely 1c, 2c and 3c, were incubated in deuterium oxide at $37^{\circ} \mathrm{C}$ for $48 \mathrm{~h}$ which were the temperature and time of the cytotoxicity experiment vide infra. The products formed were identified by ${ }^{1} \mathrm{H}-\mathrm{NMR}$ spectroscopy and are indicated in Chart 2. Since both 1c and 2c gave rise to 2-hydroxymethyl-1-(4-nitrophenyl)-2-propenone 4 , the compound was synthesized in order that its cytotoxicity could be determined.

Cytotoxicity The compounds in series $\mathbf{1}-\mathbf{4}$ were evaluated against both human WiDr colon cancer cells and human CRL-2522 foreskin fibroblasts. These data, along with the results from the assays using a reference drug namely cisplatin, are presented in Table 1.

\section{Discussion}

The biodata presented in Table 1 reveal that the compounds in series $\mathbf{1}$ and $\mathbf{2}$ are potent cytotoxics. A preliminary observation indicated that 3c was virtually devoid of potency since a concentration of $50 \mu \mathrm{m}$ of this compound caused only $1.9 \%$ and $11.1 \%$ mortalities of the WiDr and CRL-2522 cells, respectively. Hence further analogs in series 3 were not prepared.

The potencies of the compounds in series $\mathbf{1}-\mathbf{3}$ were compared with that of the established anticancer drug cisplatin whose mode of action resembles that of alkylating agents. ${ }^{21)}$ With the exception of the 4-nitro analogues $\mathbf{1 c}$ and $\mathbf{2 c}$, the compounds in series $\mathbf{1}$ and $\mathbf{2}$ are in the range of 1.5-3.7 times the potency of cisplatin when examined against human WiDr colon cancer cells. The highest potencies were displayed by 1d, 1e and 2d. In order to ascertain whether greater toxicity would be demonstrated towards tumorous cells than normal tissues, the compounds were also examined against human CRL-2522 foreskin fibroblasts. The data generated indicate that $\mathbf{1 a}, \mathbf{d}$ and $\mathbf{2 a}, \mathbf{d}$ exerted a statistically significant chemoselectivity for the malignant cells. Thus in particular 1d and $\mathbf{2 d}$ are clearly lead molecules due to the potencies displayed towards WiDr cells coupled to their tumour selectivity.

With a view to developing guidelines for the amplification of series $\mathbf{1}$ and $\mathbf{2}$, the cytotoxicity observed was evaluated with reference to both the nature of the aryl substituents and the presence of the methylene $\left(=\mathrm{CH}_{2}\right)$ group in series $\mathbf{1}$ vis$\grave{a}$-vis the hydroxymethyl function in series $\mathbf{2}$. Variation in cytotoxic potencies among the analogs in either series $\mathbf{1}$ or 2 

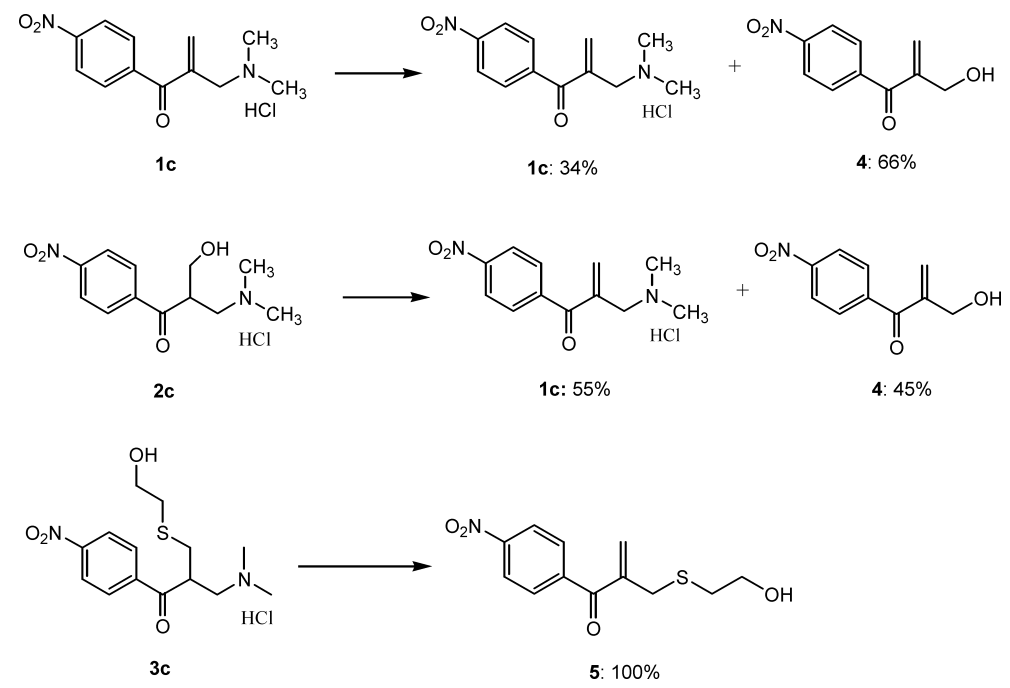

Chart 2. Stability of $\mathbf{1 c}, \mathbf{2 c}$ and $\mathbf{3 c}$ after Incubation in Deuterium Oxide at $37^{\circ} \mathrm{C}$ for $48 \mathrm{~h}$.

may be influenced by the electronic, hydrophobic and steric properties of the aryl substituents. Hence linear and semilogarithmic plots were made between the $\sigma, \pi$ and MR values of the aryl groups with the $\mathrm{IC}_{50}$ values generated in the $\mathrm{WiDr}$ and CRL-2522 assays. In series 1, a negative correlation was found between the $\sigma$ values and potencies in the WiDr screen $(p<0.05)$ indicating that cytotoxicity is favoured by electron-donating groups. This observation is counterintuitive as one would anticipate that increasing the electron density on the terminal olefinic carbon atom in series $\mathbf{1}$ would lead to diminished electrophilicity for cellular thiols and hence reduced potencies. For series 2, a similar negative correlation $(p<0.05)$ was noted in both the WiDr and CRL-2522 screens. No other correlations $(p<0.05)$ were noted.

In order to determine whether a methylene group as in series $\mathbf{1}$ or a hydroxymethyl substituent present in $\mathbf{2 a -}-\mathbf{e}$ enhanced cytotoxicity, the potencies of the analogs in series $\mathbf{1}$ and $\mathbf{2}$ which had the same aryl substituent were compared. In the WiDr assay, 1c - e were more potent than $\mathbf{2 c -}-\mathbf{e}$ while $\mathbf{1 a}, \mathbf{b}, \mathbf{2 a}, \mathbf{b}$ had statistically indistinguishable $\mathrm{IC}_{50}$ values. On the other hand, when higher $\mathrm{IC}_{50}$ values are desired in the CRL-2522 assays, 1a, e had lower potencies than 2a,e while 1c was more toxic than $\mathbf{2 c}$ and $\mathbf{1 b}, \mathbf{d}, \mathbf{2 b}, \mathbf{d}$ were equipotent. Thus from an assessment of the biodata for series $\mathbf{1}$ and $\mathbf{2}$, the following guidelines for expanding this study may be formulated. First, in terms of increasing the potencies towards WiDr cells, aryl substituents with lower $\sigma$ values than the 4methoxy substituent $\left(\sigma_{\mathrm{p}}=-0.27\right)$ should be employed. The biodata generated will enable a more thorough evaluation of whether a corresponding increase in cytotoxicity to CRL2522 cells takes place or if greater Selectivity Index values will emerge. Second, in terms of potencies to WiDr cells, the development of analogs of the enones 1 rather than the corresponding hydroxymethyl series $\mathbf{2}$ is clearly indicated. Also the data for the CRL-2522 cells suggests that higher $\mathrm{IC}_{50}$ values are found with the compounds in series 1. In summary, therefore, expansion of series $\mathbf{1}$ by inserting strongly electron-donating groups into the aryl ring is indicated.

The stability of representative compounds in series $\mathbf{1}-\mathbf{3}$ under simulated conditions of the cytotoxicity assays, viz. incubation of solutions of the compounds at $37^{\circ} \mathrm{C}$ for $48 \mathrm{~h}$,
Table 1. Evaluation of the Compounds in Series $\mathbf{1}-\mathbf{4}$ versus WiDr and CRL-2522 Cells

\begin{tabular}{crrl}
\hline \hline & \multicolumn{2}{c}{$\mathrm{LC}_{50}(\mu \mathrm{M})$} & \\
\cline { 2 - 3 } Compound & \multicolumn{1}{c}{ S.I. ${ }^{a)}$} \\
\cline { 2 - 3 } & \multicolumn{1}{c}{ WiDr } & CRL-2522 & \\
\hline $\mathbf{1 a}$ & $4.9 \pm 1.0$ & $7.2 \pm 0.5$ & $1.47^{*}$ \\
$\mathbf{1 b}$ & $4.1 \pm 0.6$ & $4.0 \pm 0.4$ & 0.91 \\
$\mathbf{1 c}$ & $8.4 \pm 0.5$ & $8.6 \pm 0.1$ & 1.02 \\
$\mathbf{1 d}$ & $2.0 \pm 0.1$ & $2.9 \pm 0.2$ & $1.45^{*}$ \\
$\mathbf{1 e}$ & $2.0 \pm 0.1$ & $2.5 \pm 0.6$ & 1.25 \\
$\mathbf{2 a}$ & $3.7 \pm 0.2$ & $4.1 \pm 0.1$ & $1.11^{*}$ \\
$\mathbf{2 b}$ & $4.5 \pm 0.3$ & $4.1 \pm 0.3$ & 0.91 \\
$\mathbf{2 c}$ & $12.8 \pm 2.4$ & $12.5 \pm 0.4$ & 0.98 \\
$\mathbf{2 d}$ & $2.5 \pm 0.3$ & $3.3 \pm 0.3$ & $1.32^{*}$ \\
$\mathbf{2 e}$ & $4.0 \pm 0.3$ & $1.4 \pm 0.2$ & 0.35 \\
$\mathbf{3 c}$ & $311 \pm 4.2$ & $218 \pm 3.4$ & 0.70 \\
$\mathbf{4}$ & $13.0 \pm 1.2$ & $13.0 \pm 1.6$ & 1.00 \\
Cisplatin & $7.4 \pm 1.7$ & $14.6 \pm 3.8$ & $1.98^{*}$ \\
& & &
\end{tabular}

a) The letters S.I. refer to the selectivity index, i.e., the ratio of the $\mathrm{IC}_{50}$ values between the CRL-2522 and WiDr cells. Figures marked with an asterisk indicate a statistically significant greater toxicity of the compound towards WiDr cells compared to CRL-2522 fibroblasts.

was undertaken for the following reasons, namely to (i) gain an insight into the possible way that the compounds behave in vitro, (ii) ascertain the likelihood of whether the compounds in series $\mathbf{2}$ and $\mathbf{3}$ are prodrugs of the enones 1, and (iii) determine the cause of the variation in cytotoxicity between series $\mathbf{1}$ and $\mathbf{2}$ on one hand and the absence of marked potency of 3c. Accordingly, the ${ }^{1} \mathrm{H}-\mathrm{NMR}$ spectra of solutions of $1 \mathbf{c}, \mathbf{2 c}$ and $\mathbf{3 c}$ in deuterium oxide were determined after $48 \mathrm{~h}$ incubation and the results are portrayed in Chart 2. The principal product obtained from the Mannich base 1c is the unsaturated alcohol 4 which presumably arose via the intermediate 2c. In addition, 1c was present which could have been formed by dehydration of $\mathbf{2 c}$ or be unreacted material. The aminoalcohol 2c produced both the dehydrated and deaminated products, namely $1 \mathrm{c}$ and 4, respectively. However 3c underwent only deamination and no dethiolation product was observed. The following conclusions were drawn from this study. First, the compounds in series $\mathbf{1}$ and $\mathbf{2}$ likely give rise to a mixture of the enones 1 and aminoalcohols 4 . Second, series $\mathbf{2}$ but not $\mathbf{3}$ appear to be prodrugs of the Mannich 
bases $\mathbf{1}$. Third, the lack of cytotoxic potency in series $\mathbf{3}$ may be explained by the absence of dethiolation which prevented the formation of the cytotoxic species $\mathbf{1}$. In order to determine whether $\mathbf{4}$ contributed to the cytotoxicity observed in series $\mathbf{1}$ and $\mathbf{2}$, this compound was examined in the WiDr and CRL-2522 assays. The $\mathrm{IC}_{50}$ figures of $\mathbf{4}$ portrayed in Table 1 reveal that this compound contributes significantly to the cytotoxicity of $\mathbf{1 c}$ and $\mathbf{2 c}$.

\section{Conclusions}

This study has demonstrated that the compounds in series $\mathbf{1}$ and $\mathbf{2}$ are potent cytotoxins most of which display significantly greater antineoplastic potencies than cisplatin. In particular, $\mathbf{1 d}$ and $\mathbf{2 d}$ are clearly lead molecules having low $\mathrm{IC}_{50}$ values when assayed against WiDr colon cancer cells and also they demonstrated a preferential cytotoxicity to these cells compared to normal fibroblasts. The stability studies revealed that the compounds in series 2 liberate the analogs in series $\mathbf{1}$. It is possible that molecular modification of the hydroxy function in series $\mathbf{2}$ may control the rate of release of the analogs in series 1 and the ratio of the released Mannich bases 1 and corresponding allyl alcohol, e.g., 4, may vary which could affect potencies and possibly give rise to increased selective toxicity for the tumorous cells rather than the fibroblasts.

\section{Experimental}

Chemistry Melting points were determined in Celsius degrees using a Gallenkamp 889339 apparatus and are uncorrected. ${ }^{1} \mathrm{H}$ - and ${ }^{13} \mathrm{C}$-NMR spectra $(500 \mathrm{MHz})$ were determined in deuterated solvents using a Bruker AM $500 \mathrm{FT}$ spectrophotometer. The letters $\mathrm{s}, \mathrm{d}, \mathrm{t}$ and $\mathrm{m}$ indicate singlet, doublet, triplet and multiplet, respectively.

Elementary analyses $(\mathrm{C}, \mathrm{H}, \mathrm{N})$ were undertaken on $\mathbf{1 b}-\mathbf{e}, \mathbf{2} \mathbf{a}-\mathbf{e}$ and $\mathbf{3 c}$ by the Microanalytical Laboratory, Department of Chemistry, University of Alberta and by Mr. K. Thoms, Department of Chemistry, University of Saskatchewan. Mass spectrometry was performed using a VG70SE mass spectrometer. Column chromatography was undertaken using silica gel 60 (70-230 mesh).

Synthesis of 1-Aryl-2-dimethylaminomethyl-prop-2-en-1-one Hydrochlorides, 1a-e. General Procedure A mixture of the appropriate acetophenone $(0.41 \mathrm{~mol})$, paraformaldehyde $(0.82 \mathrm{~mol})$ and dimethylamine hydrochloride $(0.82 \mathrm{~mol})$ in acetic acid $(750 \mathrm{ml})$ was heated under reflux for $12 \mathrm{~h}$. Acetic acid was removed in vacuo and the residue was dissolved in acetone $(500 \mathrm{ml})$. After $8 \mathrm{~h}$, the precipitate was collected, dried and purified by column chromatography using chloroform : methanol $(97: 3)$ as the eluting solvent to give the desired products $\mathbf{1 a}-\mathbf{e}$.

Compound 1a: Yield $78 \%$; mp $157^{\circ} \mathrm{C}$ (lit. ${ }^{17)} \mathrm{mp} 156-158^{\circ} \mathrm{C}$ ); ${ }^{1} \mathrm{H}-\mathrm{NMR}$ $\left(\mathrm{D}_{2} \mathrm{O}\right) \delta: 2.87(\mathrm{~s}, 6 \mathrm{H}), 4.06(\mathrm{~s}, 2 \mathrm{H}), 6.35(\mathrm{~s}, 1 \mathrm{H}), 6.60(\mathrm{~s}, 1 \mathrm{H}), 7.51(\mathrm{t}, 2 \mathrm{H})$, $7.64(\mathrm{t}, 1 \mathrm{H}), 7.71(\mathrm{~d}, 2 \mathrm{H}, J=7.10 \mathrm{~Hz})$

Compound 1b: Yield 72\%; mp $160{ }^{\circ} \mathrm{C}$; ${ }^{1} \mathrm{H}-\mathrm{NMR}\left(\mathrm{D}_{2} \mathrm{O}\right) \delta$ : $2.83(\mathrm{~s}, 6 \mathrm{H})$, $4.03(\mathrm{~s}, 2 \mathrm{H}), 6.33(\mathrm{~s}, 1 \mathrm{H}), 6.57(\mathrm{~s}, 1 \mathrm{H}), 7.49(\mathrm{~d}, 2 \mathrm{H}, J=8.30 \mathrm{~Hz}), 7.66(\mathrm{~d}$, $2 \mathrm{H}, J=8.25 \mathrm{~Hz}$ ). Found C 54.64; $\mathrm{H} 5.96 ; \mathrm{N} 5.15 \% . \mathrm{C}_{12} \mathrm{H}_{15} \mathrm{Cl}_{2} \mathrm{NO} \cdot 0.25 \mathrm{H}_{2} \mathrm{O}$ requires $\mathrm{C} 54.45 ; \mathrm{H} 5.90 ; \mathrm{N} 5.29 \%$

Compound 1c: Yield $68 \%$; mp $170{ }^{\circ} \mathrm{C} ;{ }^{1} \mathrm{H}-\mathrm{NMR}\left(\mathrm{D}_{2} \mathrm{O}\right) \delta$ : $2.85(\mathrm{~s}, 6 \mathrm{H})$, $4.06(\mathrm{~s}, 2 \mathrm{H}), 6.38(\mathrm{~s}, 1 \mathrm{H}), 6.67(\mathrm{~s}, 1 \mathrm{H}), 7.84(\mathrm{~d}, 2 \mathrm{H}, J=8.70 \mathrm{~Hz}), 8.27(\mathrm{~d}$, $2 \mathrm{H}, J=8.95 \mathrm{~Hz}$ ). Found C $52.77 ; \mathrm{H} 5.48 ; \mathrm{N} 9.95 \% . \mathrm{C}_{12} \mathrm{H}_{15} \mathrm{ClN}_{2} \mathrm{O}_{3} \cdot 0.5 \mathrm{H}_{2} \mathrm{O}$ requires $\mathrm{C} 52.32 ; \mathrm{H} 5.45 ; \mathrm{N} 10.17 \%$.

Compound 1d: Yields $72 \%$; mp $158{ }^{\circ} \mathrm{C}$; ${ }^{1} \mathrm{H}-\mathrm{NMR}\left(\mathrm{D}_{2} \mathrm{O}\right) \delta$ : $2.46(\mathrm{~s}, 3 \mathrm{H})$, $2.80(\mathrm{~s}, 6 \mathrm{H}), 4.02(\mathrm{~s}, 2 \mathrm{H}), 6.30(\mathrm{~s}, 1 \mathrm{H}), 6.53(\mathrm{~s}, 1 \mathrm{H}), 7.31(\mathrm{~d}, 2 \mathrm{H}$ $J=7.78 \mathrm{~Hz}), 7.65(\mathrm{~d}, 2 \mathrm{H}, J=7.97 \mathrm{~Hz}$ ). Found C $63.95 ; \mathrm{H} 7.43 ; \mathrm{N} 5.75 \%$. $\mathrm{C}_{13} \mathrm{H}_{18} \mathrm{ClNO} \cdot 0.5 \mathrm{H}_{2} \mathrm{O}$ requires C $63.94 ; \mathrm{H} 7.49 ; \mathrm{N} 5.32 \%$.

Compound 1e: Yield $75 \%$; mp $152{ }^{\circ} \mathrm{C}$ (lit. ${ }^{17)} \mathrm{mp} 151-152{ }^{\circ} \mathrm{C}$ ); ${ }^{1} \mathrm{H}-\mathrm{NMR}$ $\left(\mathrm{D}_{2} \mathrm{O}\right) \delta: 2.83(\mathrm{~s}, 6 \mathrm{H}), 3.85(\mathrm{~s}, 3 \mathrm{H}), 4.01(\mathrm{~s}, 2 \mathrm{H}), 6.26(\mathrm{~s}, 1 \mathrm{H}), 6.48(\mathrm{~s}, 1 \mathrm{H})$, 7.01 (d, $2 \mathrm{H}, J=8.80 \mathrm{~Hz}$ ), 7.57 (d, $2 \mathrm{H}, J=8.75 \mathrm{~Hz}$ ). Found C 60.43; H 6.81; $\mathrm{N} 5.25 \% . \mathrm{C}_{13} \mathrm{H}_{18} \mathrm{ClNO}_{2} \cdot 0.25 \mathrm{H}_{2} \mathrm{O}$ requires $\mathrm{C} 59.99 ; \mathrm{H} 7.16 ; \mathrm{N} 5.38 \%$.

Synthesis of 1-Aryl-2-dimethylaminomethyl-3-hydroxy-1-propanone Hydrochlorides 2a-e. General Procedure The crude Mannich base in series $1(20 \mathrm{~g})$ was dissolved in water $(60 \mathrm{ml})$ and the solution was basified with sodium carbonate solution $(10 \%)$ to $\mathrm{pH} 8-9$ and extracted with chloroform $(3 \times 100 \mathrm{ml})$. The combined chloroform extracts were dried over sodium sulfate and removal of the solvent in vacuo gave a viscous oil which was purified by column chromatography using an eluting solvent of chloroform:methanol $(95: 5)$. The free base was dissolved in diethyl ether $(100 \mathrm{ml})$ and after acidification with dry hydrogen chloride, a colorless solid was obtained which was collected and recrystallized from ethanol to give the aminoalcohols $\mathbf{2 a}-\mathbf{e}$

Compound 2a: Yield $60 \%$; mp $107^{\circ} \mathrm{C} ;{ }^{1} \mathrm{H}-\mathrm{NMR}\left(\mathrm{D}_{2} \mathrm{O}\right) \delta$ : $2.84(\mathrm{~s}, 3 \mathrm{H})$, $3.39(\mathrm{~d}, 1 \mathrm{H}, J=9.64 \mathrm{~Hz}), 3.88(\mathrm{~m}, 3 \mathrm{H}), 4.47(\mathrm{~m}, 1 \mathrm{H}), 7.51(\mathrm{~m}, 2 \mathrm{H}), 7.66(\mathrm{~m}$, $1 \mathrm{H}), 7.94(\mathrm{~d}, 2 \mathrm{H}, J=7.33 \mathrm{~Hz})$. Found $\mathrm{C} 51.89 ; \mathrm{H} 6.43 ; \mathrm{N} 5.01 \%$. $\mathrm{C}_{12} \mathrm{H}_{18} \mathrm{ClNO}_{2} \cdot 2 \mathrm{H}_{2} \mathrm{O}$ requires $\mathrm{C} 51.59 ; \mathrm{H} 6.44 ; \mathrm{N} 5.01 \%$.

Compound 2b: Yield $62 \%$; mp $127{ }^{\circ} \mathrm{C} ;{ }^{1} \mathrm{H}-\mathrm{NMR}\left(\mathrm{D}_{2} \mathrm{O}\right) \delta$ : $2.84(\mathrm{~s}, 3 \mathrm{H})$ $2.91(\mathrm{~s}, 3 \mathrm{H}), 3.40(\mathrm{~d}, 1 \mathrm{H}, J=9.65 \mathrm{~Hz}), 3.87(\mathrm{~m}, 3 \mathrm{H}), 4.45(\mathrm{~m}, 1 \mathrm{H}), 7.58(\mathrm{~d}$, $2 \mathrm{H}, J=8.50 \mathrm{~Hz}$ ), $7.92(\mathrm{~d}, 2 \mathrm{H}, J=8.60 \mathrm{~Hz}$ ). Found C $48.77 ; \mathrm{H} 5.51 ; \mathrm{N} 4.46 \%$. $\mathrm{C}_{12} \mathrm{H}_{17} \mathrm{Cl}_{2} \mathrm{NO}_{2} \cdot \mathrm{H}_{2} \mathrm{O}$ requires $\mathrm{C} 48.66 ; \mathrm{H} 5.78 ; \mathrm{N} 4.75 \%$.

Compound 2c: Yield $53 \% ; \mathrm{mp} 175{ }^{\circ} \mathrm{C} ;{ }^{1} \mathrm{H}-\mathrm{NMR}\left(\mathrm{D}_{2} \mathrm{O}\right) \delta: 2.83(\mathrm{~s}, 6 \mathrm{H})$ $3.38(\mathrm{~m}, 1 \mathrm{H}), 3.85-3.89(\mathrm{~m}, 3 \mathrm{H}), 4.46(\mathrm{~m}, 3 \mathrm{H}), 8.28(\mathrm{~d}, 2 \mathrm{H}, J=9.15 \mathrm{~Hz})$ $8.38(\mathrm{~d}, 2 \mathrm{H}, \quad J=8.80 \mathrm{~Hz}$ ). Found $\mathrm{C} \quad 46.44 ; \mathrm{H} \quad 5.66 ; \mathrm{N} \quad 8.59 \%$. $\mathrm{C}_{12} \mathrm{H}_{17} \mathrm{ClN}_{2} \mathrm{O}_{4} \cdot 1.25 \mathrm{H}_{2} \mathrm{O}$ requires $\mathrm{C} 46.36 ; \mathrm{H} 5.47 ; \mathrm{N} 9.01 \%$.

Compound 2d: Yield $68 \%$; mp $114{ }^{\circ} \mathrm{C}$; ${ }^{1} \mathrm{H}-\mathrm{NMR}\left(\mathrm{D}_{2} \mathrm{O}\right) \delta$ : $2.33(\mathrm{~s}, 3 \mathrm{H})$, $2.84(\mathrm{~s}, 3 \mathrm{H}), 2.90(\mathrm{~s}, 3 \mathrm{H}), 3.38(\mathrm{~d}, 1 \mathrm{H}, J=13.30 \mathrm{~Hz}), 3.87(\mathrm{~m}, 3 \mathrm{H}), 4.44(\mathrm{~m}$, $1 \mathrm{H}), 7.32(\mathrm{~d}, 2 \mathrm{H}, J=7.94 \mathrm{~Hz}), 7.85(\mathrm{~d}, 2 \mathrm{H}, J=7.62 \mathrm{~Hz})$. Found C 58.56; $\mathrm{H} 7.41 ; \mathrm{N} 4.80 \% . \mathrm{C}_{13} \mathrm{H}_{20} \mathrm{ClNO}_{2} \cdot 0.5 \mathrm{H}_{2} \mathrm{O}$ requires $\mathrm{C} 58.53 ; \mathrm{H} 7.55$; N $5.25 \%$.

Compound 2e: Yield $72 \%$; mp $138^{\circ} \mathrm{C} ;{ }^{1} \mathrm{H}-\mathrm{NMR}\left(\mathrm{D}_{2} \mathrm{O}\right) \delta$ : 2.81 (s, $3 \mathrm{H}), 2.88(\mathrm{~s}, 3 \mathrm{H}), 3.36(\mathrm{~d}, 1 \mathrm{H}, J=13.30 \mathrm{~Hz}), 3.87(\mathrm{~m}, 6 \mathrm{H}), 4.43(\mathrm{~m}, 1 \mathrm{H})$, $7.03(\mathrm{~d}, 2 \mathrm{H}, J=8.73 \mathrm{~Hz}), 7.96(\mathrm{~d}, 2 \mathrm{H}, J=8.80 \mathrm{~Hz})$. Found C 53.16; H 6.43; $\mathrm{N} 4.94 \% . \mathrm{C}_{13} \mathrm{H}_{20} \mathrm{ClNO}_{3} \cdot \mathrm{H}_{2} \mathrm{O}$ requires $\mathrm{C} 53.58 ; \mathrm{H} 6.87 ; \mathrm{N} 4.80 \%$.

Synthesis of 2-Dimethylaminomethyl-3-(hydroxyethylthio)-1-(4-nitrophenyl)-1-propanone Hydrochloride 3c A mixture of $1 \mathrm{c}(0.0035 \mathrm{~mol}), 2-$ mercaptoethanol $(0.0052 \mathrm{~mol})$ and dry chloroform $(20 \mathrm{ml})$ was stirred at $20-22^{\circ} \mathrm{C}$ for $12 \mathrm{~h}$. The solvent was removed in vacuo and the residue was recrystallized from ethanol to give $3 \mathbf{c}$ as a colorless solid. Yield $57 \%$; mp $135^{\circ} \mathrm{C} ;{ }^{1} \mathrm{H}-\mathrm{NMR}\left(\mathrm{D}_{2} \mathrm{O}\right) \delta: 2.56(\mathrm{~m}, 2 \mathrm{H}), 2.83-2.87(\mathrm{~m}, 7 \mathrm{H}), 3.04(\mathrm{~m}, 1 \mathrm{H})$, $3.50-3.53(\mathrm{~m}, 2 \mathrm{H}), 3.82(\mathrm{~m}, 1 \mathrm{H}), 4.33(\mathrm{~m}, 1 \mathrm{H}), 8.16(\mathrm{~d}, 2 \mathrm{H}, J=7.00 \mathrm{~Hz})$, $8.34(\mathrm{~d}, 2 \mathrm{H}, J=7.45 \mathrm{~Hz})$. Found C $48.19 ; \mathrm{H} 6.14 ; \mathrm{N} 7.78 \% \mathrm{C}_{14} \mathrm{H}_{21} \mathrm{ClN}_{2} \mathrm{O}_{4} \mathrm{~S}$ requires $\mathrm{C} 48.20 ; \mathrm{H} 6.07 ; \mathrm{N} 8.03 \%$.

Synthesis of 2-Hydroxymethyl-1-(4-nitrophenyl)-prop-2-en-1-one 4 A solution of $1 \mathrm{c}(1 \mathrm{~g})$ in demineralized water $(30 \mathrm{ml})$ was incubated at $37^{\circ} \mathrm{C}$ for $48 \mathrm{~h}$ and extracted with ethyl acetate $(2 \times 50 \mathrm{ml})$. The combined organic extracts were washed with water $(2 \times 50 \mathrm{ml})$ and dried over sodium sulfate. Evaporation of the solvent in vacuo gave a viscous oil which was purified by column chromatography using an eluting solvent of hexane : ethyl acetate (4:1) to give $\mathbf{4}$ as an oil.

Compound 4: Yield 35\%; ${ }^{1} \mathrm{H}-\mathrm{NMR} \delta$ : $4.56(\mathrm{~s}, 2 \mathrm{H}), 5.86(\mathrm{~s}, 1 \mathrm{H}), 6.31$ (s, $1 \mathrm{H}), 7.90(\mathrm{~d}, 2 \mathrm{H}, J=8.6 \mathrm{~Hz}), 8.33(\mathrm{~d}, 2 \mathrm{H}, J=8.7 \mathrm{~Hz}) 1 ;{ }^{13} \mathrm{C}-\mathrm{NMR} \delta: 62.75$, $124.05,129.38,130.56,143.01,146.69,150.25,196.26$; EI-MS $(m / z) 206$ $(\mathrm{M}-\mathrm{H}), 190(\mathrm{M}-\mathrm{OH})$.

Stability Study of Representative Compounds Compounds $1 \mathrm{c}, 2 \mathrm{c}$ and 3c were dissolved in deuterium oxide to form $10 \mathrm{~mm}$ solutions and the ${ }^{1} \mathrm{H}$ NMR spectra were recorded immediately on dissolution and after $48 \mathrm{~h}$ incubation at $37{ }^{\circ} \mathrm{C}$. The products formed from $1 \mathbf{c}$ and $2 \mathbf{c}$ were identified by ${ }^{1} \mathrm{H}-$ NMR spectroscopy and the relative concentrations of the compounds present in solution were obtained by comparing the intensities of the olefinic protons.

The aminoalcohol $\mathbf{3 c}$ was converted into 2-(2-hydroxyethylthiomethyl)-1(4-nitrophenyl)-prop-2-en-1-one $\mathbf{5}$ which was identified by ${ }^{1} \mathrm{H}-\mathrm{NMR}$ spectroscopy and mass spectrometry.

Compound 5: ${ }^{1} \mathrm{H}-\mathrm{NMR} \delta: 2.73(\mathrm{t}, 2 \mathrm{H}), 3.62(\mathrm{~s}, 2 \mathrm{H}), 3.74(\mathrm{t}, 2 \mathrm{H}), 5.86(\mathrm{~s}$, $1 \mathrm{H}), 6.25(\mathrm{~s}, 1 \mathrm{H}), 7.94(\mathrm{~d}, 2 \mathrm{H}, J=8.52 \mathrm{~Hz}), 8.38(\mathrm{~d}, 2 \mathrm{H}, J=8.53 \mathrm{~Hz})$. CI-MS $(\mathrm{m} / \mathrm{z}) 268.05(\mathrm{M}+\mathrm{H})^{+}, 285(\mathrm{M}+\mathrm{H}+\mathrm{Na})^{+}$.

Cytotoxicity Assay The cytotoxic potencies of the compounds prepared in this study were assessed using a standardized protocol. ${ }^{22}$ In brief, the assay employed WiDr (ATCC \# CCL 218) human colon cancer cells and CRL-2522 human BJ foreskin fibroblasts. Compounds were evaluated using concentrations of $1.56,3.13,6.25,12.5,25$ and $50 \mu \mathrm{M}$. In the case of $3 \mathbf{e}$, additional concentrations of 100,200 and $400 \mu \mathrm{M}$ were employed. After $48 \mathrm{~h}$ incubation in a humidified $5 \%$ carbon dioxide atmosphere at $37^{\circ} \mathrm{C}$, cell viability was determined using the MTT tetrazolium salt assay. ${ }^{23)}$ The $\mathrm{IC}_{50}$ value is the concentration of the compound to kill $50 \%$ of the cells and was determined from dose-response curves. The analyses were undertaken in triplicate at each concentration. 
Acknowledgements The authors thank the Canadian Institutes of Health for a grant to J. R. Dimmock (MOP-53171). I. J. Ramirez-Erosa was supported by the Agriculture Development Fund of the Government of Saskatchewan and the Maunders McNeil Foundation Inc. which are gratefully acknowledged.

\section{References}

1) Dimmock J. R., Jha A., Zello G. A., Allen T. M., Santos C. L., Balzarini J., De Clerq E., Manavathu E. K., Stables J. P., Pharmazie, 58, 227-232 (2003)

2) Dimmock J. R., Zello G. A., Oloo E. O., Quail J. W., Kraatz H.-B., Perjési P., Aradi F., Takács-Novak K., Allen T. M., Santos C. L. Balzarini J., De Clercq E., Stables J. P., J. Med. Chem., 45, 3103 3111 (2002).

3) Dimmock J. R., Smith L. M., Smith P. J., Can. J. Chem., 58, 984-991 (1980).

4) Mutus B., Wagner J. D., Talpas C. J., Dimmock J. R., Phillips O. A., Reid R. S., Anal. Biochem., 177, 237-243 (1989).

5) Dimmock J. R., Raghavan S. K., Logan B. M., Bigam G. E., Eur. J. Med. Chem., 18, 248-254 (1983).

6) Benvenuto J. A., Connor T. A., Monteith D. K., Laidlaw J. W., Adams S. C., Matney T. S., Theiss J. C., J. Pharm. Sci., 82, 988-991 (1993).

7) Dimmock J. R., Kumar P., Quail J. W., Pugazhenthi U., Yang J., Chen M., Reid R. S., Allen T. M., Kao G. Y., Cole S. P. C., Batist G., Balzarini J., De Clercq E., Eur. J. Med. Chem., 30, 209-217 (1995).

8) Dimmock J. R., Vashishtha S. C., Patil S. A., Udupa N., Dinesh S. B. Devi P. U., Kamath R., Pharmazie, 53, 702 -706 (1998).

9) Dimmock J. R., Hamon N. W., Waslen T. A., Patel S. A., Phillips O. A., Jonnalagadda S. S., Hancock D. S., Pharmazie, 41, 441-442 (1986).

10) Lesieur I., Lesieur D., Lespagnol C., Cazin M., Brunet Cl., Luyckx
M., Mallevais M. L., Delacourte A., Dubreuil L., Devos J., Romond C., Arzneim.-Forsch., 36, 20-24 (1986).

11) Mallevais M. L., Delacourte A., Lesieur I., Lesieur D., Cazin M., Brunet Cl., Luykx M., Biochemie, 66, 477-482 (1984).

12) Stein O., Stein Y., Biochem. Biophys. Acta, 306, 142-147 (1973).

13) Orci L., Le Marchand Y., Singh A., Assimacopoulos-Jeannet F., Rouiller Ch., Jeanrenaud B., Nature (London), 244, 30-32 (1973).

14) Brunet Cl., Luyckx M., Cazin M., Chaoui A., Lesieur I., Lesieur D., Delacourte A., Meth. Find. Exptl. Clin. Pharmacol., 6, 227-230 (1984).

15) Traxler P., Trinks U., Buchdunger E., Mett H., Meyer T., Müller M., Regenass U., Rösel J., Lydon N., J. Med. Chem., 38, 2441-2448 (1995).

16) Weissman B. E., Aaronson S. A., Cell, 32, 599-606 (1983).

17) Dimmock J. R., Patil S. A., Leek D. M., Warrington R. C., Fang W. D., Eur. J. Med. Chem., 22, 545-551 (1987).

18) Espinoza-Fonseca L. M., Bioorg. Med. Chem., 14, 896-897 (2006).

19) Hansch C., Leo A. J., "Substituent Constants for Correlation Analysis in Chemistry and Biology," John Wiley and Sons, New York, 1979, p. 49.

20) Remers W. A., "Wilson and Gisvold's Textbook of Organic Medicinal and Pharmaceutical Chemistry," 10th ed., ed. by Delgado J. M., Remers W. A., Lippincott-Raven, Philadelphia, PA, 1998, p. 353.

21) Remers W. A., "Wilson and Gisvold's Textbook of Organic Medicinal and Pharmaceutical Chemistry," 10th ed., ed. by Delgado J. M., Remers W. A., Lippincott-Raven, Philadelphia, PA, 1998, p. 382.

22) Promega Technical Bulletin No. 112, Cell Titre $96^{\circledR}$ Non-radioactive cell proliferation assay. Promega Corporation, Madison, WI, U.S.A., 1999, pp. 1-13.

23) Sieuwerts A. M., Klijn J. G. M., Peters H. A., Foekens J. A., Eur. J. Clin. Chem. Clin. Biochem., 33, 813-823 (1995). 